\title{
Trichoderma viride strains stimulating the growth and development of winter rapeseed (Brassica napus L.)
}

\author{
Szczepy Trichoderma viride stymulujące wzrost \\ i rozwój rzepaku ozimego (Brassica napus L.)
}

\author{
Zuzanna Znajewska, Grażyna B. Dąbrowska*, Olga Narbutt
}

\section{Summary}

The aim of the study was to examine the potential of Trichoderma viride as a factor stimulating the growth of winter rapeseed (Brassica napus L.). It was proved that T. viride strains that differ in growth rate and represent various antagonism towards plant pathogens, stimulate root growth and inhibit the elongation of hypocotyls of winter rapeseed seedlings. It was found that the presence of $T$. viride in winter rapeseed promoted the intense development of lateral roots. Treating seeds of winter rapeseed with spores of $T$. viride 154 and T. viride DAR5 had a positive effect on the growth and development of plants in the pot experiment. It was demonstrated that both Trichoderma strains increased fresh and dry biomass. Higher than fourfold increase of the fresh biomass and three and a half increase of dry biomass of winter rapeseed were recorded in the presence of $T$. viride DAR5 in comparison to the control plants. Population density of bacteria was higher while the fungi lower in the rhizosphere of winter rapeseed plants treated with $T$. viride as compare to the control.

Key words: winter rapeseed; Brassica napus; seed treatment; Trichoderma; plants growth stimulation

\section{Streszczenie}

Celem badań było sprawdzenie potencjału Trichoderma viride do stymulowania wzrostu rzepaku ozimego. Wykazano, że szczepy T. viride różniące się tempem wzrostu i wykazujące różny antagonizm w stosunku do patogenów roślin, stymulują wzrost korzeni, a hamują elongację hypokotyli siewek rzepaku. Stwierdzono, że obecność T. viride u rzepaku promowała intensywny rozwój korzeni bocznych. Szczepienie nasion rzepaku sporami grzybów T. viride 154 i T. viride DAR5 wpływało pozytywnie na wzrost i rozwój roślin w eksperymencie donicowym. Wykazano zwiększenie świeżej i suchej biomasy przez oba szczepy Trichoderma. W obecności T. viride DAR5 zanotowano ponad czterokrotny wzrost świeżej biomasy oraz ponad trzykrotny suchej masy rzepaku w porównaniu do roślin kontrolnych. W ryzosferze roślin rzepaku szczepionych sporami T. viride liczebność populacji bakterii była wyższa, a grzybów niższa w porównaniu do kontroli.

Słowa kluczowe: rzepak ozimy; Brassica napus; szczepienie nasion; Trichoderma; stymulacja wzrostu roślin

\footnotetext{
Uniwersytet Mikołaja Kopernika w Toruniu

Wydział Biologii i Ochrony Środowiska

Zakład Genetyki

Lwowska 1, 87-100 Toruń

*corresponding author: browsk@umk.pl
} 


\section{Wstęp / Introduction}

Uprawy rzepaku (Brassica napus L. spp. oleifera) stanowią 95-97\% upraw roślin oleistych w Polsce (Izdebski i wsp. 2014). Polska jest czwartym w Europie producentem, przetwórcą i eksporterem rzepaku. Chiny wytwarzają najwięcej, bo aż ponad 80\% światowej produkcji rzepaku. Kolejni producenci to Indie oraz Kanada (Wang i wsp. 2009). Rośliny uprawne są narażone na działanie czynników środowiskowych, takich jak: nadmierne zasolenie gleby, niedobór wody (Fujita i wsp. 2006), obecność metali ciężkich (Dąbrowska i wsp. 2017) czy mikroorganizmów ryzosferowych (Dąbrowska i wsp. 2014), a w tym również patogenów (Mączyńska i wsp. 2001).

Jednym ze sposobów ochrony roślin przed stresami biotycznymi i abiotycznymi jest stosowanie biopreparatów zawierających mikroorganizmy (Martyniuk 2011; Dąbrowska i Zdziechowska 2015). Stosowanie środków do ochrony upraw zawierających drobnoustroje jest jednym $\mathrm{z}$ elementów zrównoważonej produkcji rolnej, gdyż ogranicza uwalnianie do środowiska zanieczyszczeń powodowanych nadmiernym stosowaniem nawozów mineralnych oraz chemicznych środków ochrony roślin (Mishra i wsp. 2011). Często składnikami biopreparatów są grzyby z rodzaju Trichoderma (Martyniuk 2011). Grzyby te charakteryzują się szybkim tempem wzrostu, obfitym zarodnikowaniem, zdolnością do wytwarzania substancji fungitoksycznych (głównie antybiotyków peptydowych) i enzymów hydrolitycznych (Benítez i wsp. 2004; Nawrocka i Małolepsza 2013). Od wielu lat grzyby te stosowane są do ochrony roślin przed patogenami (Druzhinina i wsp. 2011; Kowalska 2014). Grzyby z rodzaju Trichoderma charakteryzują się dużymi zdolnościami adaptacyjnymi, co umożliwia kolonizację nisz ekologicznych (Okorski i wsp. 2014), zaliczane są do grzybów stymulujących wzrost roślin (Plant Growth Promoting Fungi - PGPF) (Keswani i wsp. 2014; Oskiera i wsp. 2015). Maag i wsp. (2014) wykazali stymulujący wpływ Trichoderma atroviride na wzrost rzepaku. Jednakże w warunkach nadmiernego rozwoju, grzyby z rodzaju Trichoderma mogą oddziaływać negatywnie na wzrost i rozwój roślin (Perek i wsp. 2013; Kosicka i wsp. 2014; Liu i wsp. 2017). Znane są mikroorganizmy ryzosferowe stymulujące wzrost rzepaku w zależności od fazy rozwoju czy obecności czynników negatywnie oddziałujących na rośliny (Dąbrowska i wsp. 2012, 2014; Farina i wsp. 2012). Mimo, że w literaturze jest wiele informacji na temat grzybów Trichoderma sp. $\mathrm{i}$ ich znaczenia w uprawach, to jednak niewiele jest danych dotyczących wpływu szczepów T. viride na wzrost i rozwój rzepaku.

Celem pracy była ocena możliwości wykorzystania dwóch szczepów $T$. viride (154 i DAR5) do stymulowania wzrostu i rozwoju rzepaku (B. napus spp. oleife$r a)$ oraz analiza liczebności populacji bakterii i grzybów w glebie szczepionej T. viride 153 i T. viride DAR5 różnią- cymi się tempem wzrostu i wykazującymi różny antagonizm w stosunku do patogenów roślin.

\section{Materiały i metody / Materials and methods}

Materiał badawczy stanowiły nasiona $B$. napus odmiany ozimej Harry oraz dwa szczepy grzyba saprofitycznego T. viride: 154 i DAR5, udostępnione przez prof. Katarzynę Hrynkiewicz z Zakładu Mikrobiologii Uniwersytetu Mikołaja Kopernika w Toruniu. Do badań wybrano dwa szczepy różniące się tempem wzrostu. Szczep T. viride DAR5 charakteryzuje się szybszym wzrostem w porównaniu ze szczepem T. viride 154 (Dąbrowska i wsp. 2016).

\section{Przygotowanie inokulum grzybowego}

Szczepy Trichoderma hodowano na podłożu stałym PDA (Potato Dextrose Agar) (LabM, UK) w temperaturze $23^{\circ} \mathrm{C}$. Dwutygodniową grzybnię $T$. viride przenoszono sterylnym skalpelem na filtr Miracloth (Millipore Corp., USA) i przepłukiwano sterylną wodą. Zawartość spor w przesączu sprawdzano za pomocą hemocytometru. Do doświadczenia przeprowadzonego $\mathrm{w}$ warunkach laboratoryjnych przygotowano zawiesiny o gęstości spor: $1 \times 10^{7}, 1 \times 10^{8}, 1 \times 10^{9} / \mathrm{cm}^{3}$. Natomiast zawiesina o gęstości zarodników $1 \times 10^{7} / \mathrm{cm}^{3}$ została użyta w eksperymencie donicowym.

\section{Wzrost siewek rzepaku w obecności Trichoderma viride w warunkach laboratoryjnych}

Nasiona rzepaku ozimego odmiany Harry sterylizowano zgodnie z procedurą opisaną w pracy Mierek-Adamska i wsp. (2018). Wysterylizowane nasiona umieszczano na 10 minut w sterylnej wodzie (próba kontrolna) lub w zawiesinach zawierających spory T. viride 154 lub T. viride DAR5 o gęstościach spor: $1 \times 10^{7}, 1 \times 10^{8}, 1 \times 10^{9} / \mathrm{cm}^{3}$. Następnie wykładano po 30 nasion na płytki Petriego zawierające sterylną bibułę nasączoną $8 \mathrm{ml}$ sterylnej wody i inkubowano przez 6 dni w ciemności w temperaturze $23^{\circ} \mathrm{C}$. W ramach każdego wariantu w taki sam sposób przygotowano po trzy powtórzenia. Po zakończeniu hodowli zliczano skiełkowane nasiona, mierzono długość korzeni i hypokotyli siewek oraz ważono świeżą i suchą biomasę. Suchą biomasę oznaczano na podstawie wagi materiału roślinnego suszonego przez 48 godzin w temperaturze $105^{\circ} \mathrm{C}$. Doświadczenie wykonano w trzech powtórzeniach technicznych i trzech biologicznych.

\section{Analiza wzrostu rzepaku szczepionego Trichoderma viride - eksperyment szklarniowy}

W donicach o objętości $2000 \mathrm{dm}^{3}$ wypełnionych ziemią ogrodową (K: 250-350 mg/l, $\mathrm{N}:$ 150-250 mg/l, P: 100-200 mg/1, pH 6,0-6,5) umieszczano nasiona rzepaku ozimego odmiany Harry, które inkubowano przez $10 \mathrm{mi}$ - 
nut w zawiesinie spor T. viride 154 lub T. viride DAR5 lub w wodzie (próba kontrolna). W każdej donicy umieszczano po sześć nasion, po ich skiełkowaniu w donicy pozostawiono trzy rośliny w tym samym stadium rozwojowym. Dla każdego wariantu przygotowano 10 donic. Rośliny B. napus rosły w warunkach szklarniowych przez 16 tygodni, w miesiącach od lutego do czerwca, w temperaturze $23-25^{\circ} \mathrm{C}$. Przez cały okres wegetacji, w donicach kontrolowano wilgotność gleby, którą utrzymywano na poziomie $70-75 \%$ pełnej pojemności wodnej. Po zakończeniu doświadczenia oceniano długość części nadziemnej roślin i korzeni, liczbę międzywęźli oraz świeżą i suchą biomasę. Dla każdego wariantu analizowano po 30 roślin.

\section{Liczebność mikroorganizmów w glebie z ryzosfery rzepaku $z$ eksperymentu donicowego}

W celu sprawdzenia liczebności mikroorganizmów w glebie z ryzosfery rzepaku, z poszczególnych donic pobierano po $10 \mathrm{~g}$ gleby ze strefy korzeniowej, którą przenoszono do $90 \mathrm{~cm}^{3}$ sterylnej wody, a następnie wytrząsano przez 10 minut. Zawiesinę glebową, metodą seryjnych rozcieńczeń doprowadzono do rozcieńczenia $10^{7}$. Posiewy lane wykonano dla bakterii na podłożu R2A (Difco, USA) z nystatyną o końcowym stężeniu $100 \mu \mathrm{M}$, a dla grzybów na podłożu stałym PDA (LabM, UK) z tetracykliną o końcowym stężeniu $100 \mu \mathrm{M}$. Do zliczenia kolonii bakteryjnych wybrano rozcieńczenia: $10^{5}, 10^{6}, 10^{7}$, a grzybów $10^{3}$, $10^{4}$ oraz $10^{5}$. Testowano różne rozcieńczenia, aby zoptymalizować metodę tak, aby możliwe było uzyskanie na poszczególnych płytkach kolonii. Płytki inkubowano w temperaturze $23^{\circ} \mathrm{C}$, a kolonie bakterii i grzybów zliczano w 3, 7 i 10 dniu wzrostu.

\section{Analiza statystyczna}

Analizę statystyczną uzyskanych wyników wykonano przy użyciu oprogramowania PAST (Hammer i wsp. 2001). Istotność statystyczną uzyskanych wyników sprawdzono za pomocą jednoczynnikowej analizy wariancji (one-way ANOVA) oraz testu post-hoc Tukeya. Za próg istotności przyjęto wartość $\mathrm{p} \leq 0,05$.

\section{Wyniki i dyskusja / Results and discussion}

\section{Wzrost i rozwój siewek rzepaku w obecności grzybów Trichoderma w warunkach laboratoryjnych i w eksperymencie donicowym}

W eksperymencie laboratoryjnym sprawdzono wpływ szczepienia nasion zawiesinami spor $T$. viride $154 \mathrm{i} T$. viride DAR5 o gęstościach: $1 \times 10^{7}, 1 \times 10^{8}, 1 \times 10^{9} / \mathrm{cm}^{3}$ na wzrost i rozwój siewek rzepaku ozimego. Oba szczepy charakteryzują się antagonizmem w stosunku do patogenów roślin (Thiem i wsp. 2014; Dąbrowska i wsp. 2016). Wykazano, że obecność T. viride DAR5 powodowała zwiększenie liczby skiełkowanych nasion niemal o $20 \% \mathrm{w}$ porównaniu do nasion nieszczepionych (dane nieprezentowane). Wszystkie zastosowane rozcieńczenia zawiesiny spor szczepu $T$. viride 154 oddziaływały pozytywnie na wzrost korzeni siewek rzepaku, najlepsze efekty obserwowano przy inokulum $1 \times 10^{7} / \mathrm{cm}^{3}$ i $1 \times 10^{8} / \mathrm{cm}^{3}$. W przypadku szczepu $T$. viride DAR5 korzenie roślin były istotnie dłuższe w wariancie, w którym wykorzystano zawiesinę spor o gęstości $1 \times 10^{7} / \mathrm{cm}^{3}$, w stężeniach o mniejszej ilości spor nie zaobserwowano dłuższych korzeni w stosunku do roślin kontrolnych. Obecność obu szczepów $T$. viride hamowała elongację hypokotyli siewek (rys. 1). Podobnie Sobolewski i wsp. (2013) wykazali korzystny wpływ zaprawiania nasion izolatami Trichoderma spp. na wysokość siewek marchwi $\mathrm{i}$ ich masę. W pracy Ali i wsp. (2014) w badaniach in vitro opisano stymulujący wpływ Trichoderma (T. harzianum, T. viride i T. koningii) na kiełkowanie nasion, długość korzeni i pędów siewek ciecierzycy. Natomiast szczepienie nasion chili T. harzianum zwiększało liczbę skiełkowanych nasion w warunkach laboratoryjnych i wzrost roślin w warunkach polowych (Asaduzzaman i wsp. 2010).

Oceniono także wpływ izolatów T. viride 154 i T. viride DAR5 na wzrost i rozwój roślin rzepaku w eksperymencie donicowym (tab. 1). Wykazano, że rośliny szczepione T. viride 154 lub T. viride DAR5 charakteryzowały się dłuższymi korzeniami, pędami i liczbą międzywęźli. Korzenie i pędy roślin szczepionych grzybami były niemal dwukrotnie dłuższe niż roślin kontrolnych. Obecność grzybów stymulowała rozwój korzeni bocznych, zwłaszcza w przypadku szczepienia $T$. viride DAR5. Wykazano, że grzyby $\mathrm{z}$ rodzaju Trichoderma, występujące w ryzosferze zdolne są do syntetyzowania kwasu indolilooctowego, co przyczynia się do stymulowania wzrostu korzeni (Nieto-Jacobo i wsp. 2017). Stymulujący efekt T. atroviride na wzrost korzeni i pędów oraz biomasę rzepaku, pokazały badania Maag i wsp. (2014), chociaż szczep ten nie indukował systemicznej oporności na Plutella xylosella u tej rośliny.

Izolaty $T$. viride $154 \mathrm{i} T$. viride DAR5 zastosowane donasiennie wpływały na istotny wzrost świeżej i suchej biomasy rzepaku. W przypadku szczepu T. viride 154 stwierdzono ponad trzykrotny wzrost świeżej biomasy, a w przypadku suchej biomasy wzrost o ponad dwa i pół razy większy w porównaniu do roślin nieinokulowanych sporami. Natomiast świeża i sucha masa roślin szczepionych $T$. viride DAR5 była niemal czterokrotnie większa w porównaniu do roślin kontrolnych. Podobnie w przypadku innych roślin uprawnych, buraka ćwikłowego i marchwi, stosowanie grzybów Trichoderma sp. jako zaprawy nasiennej wpływało pozytywnie na kiełkowanie nasion i stan siewek (Sadowski i wsp. 2005; Sobolewski i wsp. 2013). Mastouri i wsp. (2010) wykazali korzystny wpływ zaprawy nasiennej, zawierającej Trichoderma sp. na kiełkowanie i wzrost pomidora, również w warunkach stresu biotycznego. 

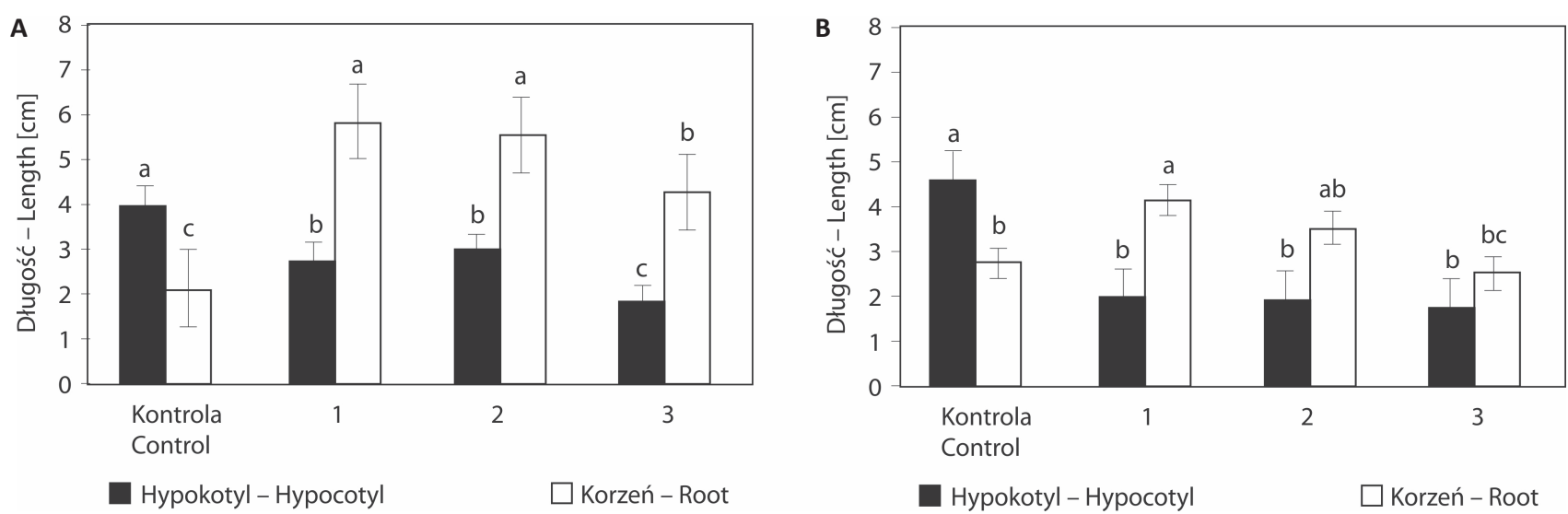

Słupki przedstawiają średnią z pomiarów z trzech powtórzeń biologicznych doświadczenia \pm odchylenie standardowe. Różnice istotne statystycznie przy $\mathrm{p} \leq 0,05$

The bars represent the mean of the measurements from three biological repetitions of experiment \pm standard deviation. The statistically significant differences at $\mathrm{p} \leq 0.05$

Rys. 1. Długość hypokotyli i korzeni 6-dniowych siewek Brassica napus nieinokulowanych (kontrola) lub inokulowanych zawiesinami spor szczepów (A) Trichoderma viride 154 i (B) Trichoderma viride DAR5, o gęstościach spor: $1-1 \times 10^{7}, 2-1 \times 10^{8}$, $3-1 \times 10^{9} / \mathrm{cm}^{3}$

Fig. 1. Length of hypocotyl and roots of 6-day seedlings of Brassica napus, untreated seeds (control) or treated with spores of (A) Trichoderma viride 154 and (B) Trichoderma viride DAR5, spore density: $1-1 \times 10^{7}, 2-1 \times 10^{8}, 3-1 \times 10^{9} / \mathrm{cm}^{3}$

Tabela 1. Wpływ szczepów Trichoderma viride 154 i Trichoderma viride DAR5 na wzrost i rozwój oraz biomasę 16-tygodniowych roślin rzepaku $(\mathrm{n}=30)$

Table 1. Effect of Trichoderma viride 154 and Trichoderma viride DAR5 on the growth, development and biomass of 16-week winter rapeseed plants $(\mathrm{n}=30)$

\begin{tabular}{l|c|c|c|c|c}
\hline & $\begin{array}{c}\text { Długość pędów } \\
\text { Length of shoot } \\
{[\mathrm{cm}]}\end{array}$ & $\begin{array}{c}\text { Długość korzeni } \\
\text { Root length } \\
{[\mathrm{cm}]}\end{array}$ & $\begin{array}{c}\text { Liczba } \\
\text { międzywęźli } \\
\text { Internodes } \\
\text { per plant }\end{array}$ & $\begin{array}{c}\text { Swieża biomasa } \\
\text { Fresh biomass } \\
{[\mathrm{g}]}\end{array}$ & $\begin{array}{c}\text { Sucha biomasa } \\
\text { Dry biomass } \\
{[\mathrm{g}]}\end{array}$ \\
\hline Kontrola - Control & $29,5 \pm 4,9 \mathrm{~b}$ & $6,1 \pm 1,9 \mathrm{~b}$ & $8 \pm 1,32 \mathrm{~b}$ & $2,48 \pm 1,37 \mathrm{~b}$ & $0,24 \pm 0,18 \mathrm{~b}$ \\
\hline Trichoderma viride 154 & $42,2 \pm 5,1 \mathrm{a}$ & $12,2 \pm 2,7 \mathrm{a}$ & $9 \pm 1,09 \mathrm{ab}$ & $7,93 \pm 3,32 \mathrm{a}$ & $0,63 \pm 0,27 \mathrm{a}$ \\
\hline Trichoderma viride DAR5 & $45,3 \pm 3,3 \mathrm{a}$ & $11,5 \pm 1,6 \mathrm{a}$ & $9 \pm 1,00 \mathrm{a}$ & $10,67 \pm 3,29 \mathrm{a}$ & $0,82 \pm 0,32 \mathrm{a}$ \\
\hline
\end{tabular}

W tabeli zestawiono wartości średnie \pm odchylenie standardowe. Wyniki oznaczone różnymi literami różnią się istotnie statystycznie przy p $\leq 0,05$

The table summarizes the mean \pm standard deviation. Values indicted by the different letters differ are significantly different at $\mathrm{p} \leq 0.05$

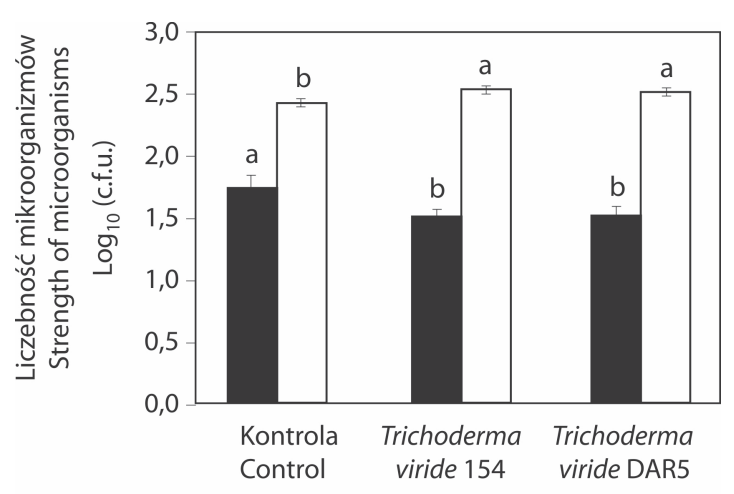

Grzyby - Fungi $\square$ Bakterie - Bacteria

Rys. 2. Liczebności bakterii i grzybów w glebie z ryzosfery rzepaku z eksperymentu donicowego. Słupki przedstawiają średnią $\mathrm{z}$ trzech powtórzeń doświadczenia \pm odchylenie standardowe, $\mathrm{p} \leq 0,05$

Fig. 2. Population density of bacteria and fungi in the soil from rhizosphere of winter rapeseed plants from the pot experiment. The bars represent the average of three replicates of experience \pm standard deviation at $\mathrm{p} \leq 0.05$

\section{Liczebności mikroorganizmów w glebie z ryzosfery rzepaku z eksperymentu donicowego}

Sprawdzono liczebność mikroorganizmów w glebie z ryzosfery rzepaku ozimego, pochodzącej z eksperymentu donicowego. Liczebność bakterii była większa w glebie, w której rosły rośliny szczepione $T$. viride 154 i DAR5 niż w kontroli (rys. 2). Natomiast w glebie nieszczepionej obserwowano największą liczebność grzybów. Podobnie, ograniczenie liczebności grzybów w glebie, w której rósł rzepak stwierdzono w badaniach Janczak i wsp. (2018). Obserwowany wzrost liczebności bakterii może być spowodowany korzystnym wpływem rzepaku, rośliny nietworzącej mikoryz na autochtoniczne bakterie glebowe. Obecność grzybów z rodzaju Trichoderma w glebie może powodować obniżenie jej odczynu i przyczyniać się do ograniczania rozwoju innych mikroorganizmów, a jednocześnie wpływać na zwiększenie dostępności składników odżywczych (Smolińska i wsp. 2014). Mar Vázquez i wsp. (2000) spraw- 
dzili wpływ Trichoderma sp. na liczebność innych organizmów glebowych w ryzosferze kukurydzy. Liczba grzybów w glebie wzrastała istotnie statystycznie po inokulacji gleby szczepami Trichoderma sp. także w obecności arbuskularnych grzybów mykoryzowych. Jednakże inokulacja Trichoderma sp. nie prowadziła do wzrostu liczebności Pseudomonas i Azospirillum w ryzosferze.

Istnieje potrzeba opracowania nowych rozwiązań i preparatów pochodzenia biologicznego, jako odpowiedź i alternatywa na wciąż stosowane chemiczne środki ochrony roślin. Zastosowane w badaniach szczepy $T$. viride mogą stanowić składniki biopreparatów stymulujących wzrost i rozwój rzepaku. Kolejnym etapem będzie przeprowadzenie badań w warunkach polowych w celu potwierdzenia ich skuteczności w warunkach naturalnych i w obecności stresu solnego lub suszy. Przeprowadzone badania pozwoliły na zidentyfikowanie izolatów $T$. viride, które prawdopodobnie należą do istotnych czynników odgrywających ważną rolę w środowisku wzrostu rzepaku, rośliny nietworzącej my- koryz. Wyniki przeprowadzonych doświadczeń wykazują, że potencjalne biopreparaty zawierające $T$. viride 154 lub T. viride DAR5 mogą znaleźć zastosowanie w uprawach rzepaku.

\section{Wnioski / Conclusions}

1. Szczepy T. viride stymulują wzrost siewek i wpływają na wzrost suchej i świeżej biomasy rzepaku ozimego.

2. W glebie, w której rósł rzepak wysiany z nasion szczepionych izolatami grzybów z rodzaju Trichoderma liczebność bakterii glebowych wzrastała, a zmniejszała się populacja grzybów.

Praca finansowana z działalności statutowej Uniwersytetu Mikołaja Kopernika w Toruniu.

\section{Literatura / References}

Ali A., Haider M.S., Ashfaq M. 2014. Effect of culture filtrates of Trichoderma spp. on seed germination and seedling growth in chickpea - an in-vitro study. Pakistan Journal of Phytopathology 26 (1): 1-5.

Asaduzzaman M., Alam M.J., Islam M.M. 2010. Effect of Trichoderma on seed germination and seedling parameters of chili. Journal of Science Foundation 8 (1-2): 141-150. DOI: 10.3329/jsf.v8i1-2.14637.

Benítez T., Rincón A.M., Limón M.C., Codón A.C. 2004. Biocontrol mechanisms of Trichoderma strains. International Microbiology 7 (4): 249-260.

Dąbrowska G., Hrynkiewicz K., Mierek-Adamska A., Goc A. 2012. Wrażliwość odmian jarych i ozimych rzepaku na metale ciężkie i bakterie glebowe. [The sensitivity of spring and winter varieties of oilseed rape to heavy metals and rhizobacteria]. Rośliny Oleiste - Oilseed Crops 33 (2): 201-220. DOI: 10.5604/12338273.1058112.

Dąbrowska G., Hrynkiewicz K., Trejgell A. 2014. Do arbuscular mycorrhizal fungi affect metallothionein MT2 expression in Brassica napus L. roots? Acta Biologica Cracoviensia Series Botanica 54 (1): 34-39. DOI: 10.2478/v10182-012-0003-1.

Dąbrowska G., Hrynkiewicz K., Trejgell A., Baum C. 2017. The effect of plant growth-promoting rhizobacteria on the phytoextraction of $\mathrm{Cd}$ and Zn by Brassica napus L. International Journal of Phytoremediation 19 (7): 597-604. DOI: 10.1080/15226514.2016.1244157.

Dąbrowska G., Zdziechowska E. 2015. Rola bakterii ryzosferowych w stymulacji procesów wzrostu i rozwoju oraz ochronie roślin przed czynnikami środowiska. [The role of rhizobacteria in the stimulation of the growth and development processes and protection of plants against environmental factors]. Progress in Plant Protection 55 (4): 498-506. DOI: 10.14199/ppp-2015-083.

Dąbrowska G., Znajewska Z., Mierek-Adamska A., Hrynkiewicz K. 2016. Trichoderma as potential factor for biocontrol of the soil microbiome. p. 1-92. Biodiversity conservation on farmlands at crossroads: international conference. Institute of Soil Science and Plant Cultivation - State Research Institute in Puławy, 27-28 September 2016, p. 54.

Druzhinina I.S., Seidl-Seiboth V., Herrera-Estrella A., Horwitz B.A., Kenerley C.M., Monte E., Mukherjee P.K., Zeilinger S., Grigoriev I.V., Kubicek C.P. 2011. Trichoderma: the genomics of opportunistic success. Nature Reviews Microbiology 9 (10): 749-759. DOI: 10.1038/nrmicro2637.

Farina R., Beneduzi A., Ambrosini A., de Campos S.B., Lisboa B.B., Wendisch V., Vargas L.K., Passaglia L.M.P. 2012. Diversity of plant growth-promoting rhizobacteria communities associated with the stages of canola growth. Applied Soil Ecology 55: 44-52. DOI: 10.1016/j.apsoil.2011.12.011.

Fujita M., Fujita Y., Noutoshi Y., Takahashi F., Narusaka Y., Yamaguchi-Shinozaki K., Shinozaki K. 2006. Crosstalk between abiotic and biotic stress responses: a current view from the points of convergence in the stress signaling networks. Current Opinion in Plant Biology 9 (4): 436-442. DOI: DOI: 10.1016/j.pbi.2006.05.014.

Hammer Ø., Harper D.A.T., Ryan P.D. 2001. PAST: paleontological statistics software package for education and data analysis. Palaeontologia Electronica 4 (1): 1-9.

Izdebski W., Jakubowski Z., Skudlarski J., Zając S., Maznev G.E., Zaika S.A. 2014. Stan i perspektywy produkcji rzepaku w Polsce i na Ukrainie w aspekcie produkcji biopaliw transportowych. [Status and prospects of rapeseed production in Poland and Ukraine in terms of transportation biofuels production]. Zeszyty Naukowe Szkoły Głównej Gospodarstwa Wiejskiego w Warszawie. Problemy Rolnictwa Światowego 14 (29): 80-89.

Janczak K., Hrynkiewicz K., Znajewska Z., Dąbrowska G. 2018. Use of rhizosphere microorganisms in the biodegradation of PLA and PET polymers in compost soil. International Biodeterioration and Biodegradation 130: 65-75. DOI: 10.1016/j.ibiod.2018.03.017.

Keswani C., Mishra S., Sarma B.K., Singh S.P., Singh H.B. 2014. Unraveling the efficient applications of secondary metabolites of various Trichoderma spp. Applied Microbiology and Biotechnology 98 (2): 533-544. DOI: 10.1007/s00253-013-5344-5. 
Kosicka D., Wolna-Maruwka A., Trzeciak M. 2014. Aspekty stosowania Trichoderma sp. w ochronie roślin i rozkładzie materii organicznej. [Aspects of the use of Trichoderma sp. in crop protection and distribution of organic matter]. Kosmos Problemy Nauk Biologicznych 63 (4): 635-642.

Kowalska J. 2014. Organically grown Brassica napus - use of border strips and Trichoderma. Acta Agriculturae Scandinavica, Section B - Soil \& Plant Science 64 (6): 529-536. DOI: 10.1080/09064710.2014.929730.

Liu N.Y., Bao Z.R., Li J., Ao X.Y., Zhu J.Y., Chen Y.H. 2017. Identification of differentially expressed genes from Trichoderma atroviride strain SS003 in the presence of cell wall of Cronartium ribicola. Genes \& Genomics 39 (5): 473-484. DOI: 10.1007/s13258-0160512-5.

Maag D., Kandula D.R.W., Müller C., Mendoza-Mendoza A., Wratten S.D., Stewart A., Rostás M. 2014. Trichoderma atroviride LU132 promotes plant growth but not induced systemic resistance to Plutella xylostella in oilseed rape. BioControl 59 (2): 241-252. DOI: 10.1007/s10526-013-9554-7.

Mar Vázquez M., César S., Azcón R., Barea J.M. 2000. Interactions between arbuscular mycorrhizal fungi and other microbial inoculants (Azospirillum, Pseudomonas, Trichoderma) and their effects on microbial population and enzyme activities in the rhizosphere of maize plants. Applied Soil Ecology 15 (3): 261-272. DOI: 10.1016/S0929-1393(00)00075-5.

Martyniuk S. 2011. Skuteczne i nieskuteczne preparaty mikrobiologiczne stosowane w ochronie i uprawie roślin oraz rzetelne i nierzetelne metody ich oceny. Postępy Mikrobiologii 50 (4): 321-328.

Mastouri F., Björkman T., Harman G.E. 2010. Seed treatment with Trichoderma harzianum alleviates biotic, abiotic, and physiological stresses in germinating seeds and seedlings. Phytopathology 100 (11): 1213-1221. DOI: 10.1094/PHYTO-03-10-0091.

Mączyńska A., Głazek M., Krzyzińska B., Banachowska J. 2001. Porażenie przez grzyby chorobotwórcze roślin rzepaku ozimego w latach 1999 i 2000. [Occurrence of winter oilseed rape pathogens in 1999 and 2000 years]. Rośliny Oleiste 22: 127-138.

Mierek-Adamska A., Znajewska Z., Goc A., Dąbrowska G.B. 2018. Molecular cloning and characterization of Ipomoea nil metallothioneins. Turkish Journal of Botany 42: 247-256. DOI: 10.3906/bot-1707-26.

Mishra B.K., Mishra R.K., Mishra R.C., Tiwari A.K., Yadav R.S., Dikshit A. 2011. Biocontrol efficacy of Trichoderma viride isolates against fungal plant pathogens causing disease in Vigna radiata L. Archives of Applied Science Research 3 (2): 361-369.

Nawrocka J., Małolepsza U. 2013. Diversity in plant systemic resistance induced by Trichoderma. Biological Control 67 (2): $149-156$. DOI: 10.1016/j.biocontrol.2013.07.005.

Nieto-Jacobo M.F., Steyaert J.M., Salazar-Badillo F.B., Nguyen D.V., Rostás M., Braithwaite M., De Souza J.T., Jimenez-Bremont J.F., Ohkura M., Stewart A., Mendoza-Mendoza A. 2017. Environmental growth conditions of Trichoderma spp. affects indole acetic acid derivatives, volatile organic compounds, and plant growth promotion. Frontiers in Plant Science 8: 102. DOI: 10.3389/ fpls.2017.00102.

Okorski A., Oszako T., Nowakowska J.A., Pszczółkowska A. 2014. Możliwości biologicznej ochrony roślin przed chorobami w szkółkarstwie, ze szczególnym uwzględnieniem lęgniowców (Oomycetes) i grzybów z rodzaju Fusarium. [The possibilities of biologically protecting plants against diseases in nurseries, with special consideration of Oomycetes and Fusarium fungi]. Leśne Prace Badawcze 75 (3): 301-321. DOI: 10.2478/frp-2014-0029.

Oskiera M., Szczech M., Bartoszewski G. 2015. Molecular identification of Trichoderma strains collected to develop plant growth-promoting and biocontrol agents. Journal of Horticultural Research 23 (1): 75-86. DOI: 10.2478/johr-2015-0010.

Perek A., Krzymińska J., Świerszczyńska I. 2013. Porównanie antagonistycznego oddziaływania grzybów z rodzaju Trichoderma oraz grzybów drożdżoidalnych na patogeny z rodzaju Fusarium w warunkach in vitro. [Comparison of the antagonistic effect of Trichoderma spp. and yeasts on pathogenic Fusarium spp. in in vitro conditions]. Journal of Research and Applications in Agricultural Engineering 58 (4): 99-103.

Sadowski C., Pańka D., Lenc L., Domoradzki M. 2005. Badania nad możliwością wykorzystania biopreparatów do otoczkowania nasion warzyw ekologicznych. [Research on possibility of use of biopreparations for organic vegetable seed coating]. Progress in Plant Protection/Postępy w Ochronie Roślin 45 (2): 1055-1057.

Smolińska U., Gołębiewska E., Kowalska B., Kowalczyk W., Szczech M. 2014. Materiały odpadowe jako nośniki antagonistycznych grzybów Trichoderma. [Waste materials as growing media for antagonistic Trichoderma fungi]. Inżynieria i Ochrona Środowiska 17 (1): 5-20.

Sobolewski J., Gidelska A., Szczech M., Robak J. 2013. Trichoderma spp. jako zaprawa nasienna przeciwko zgorzelom siewek roślin warzywnych. [Trichoderma spp. as a seed dressing bioproduct against damping-off seedlings of vegetables crops]. Progress in Plant Protection/Postępy w Ochronie Roślin 53 (2): 340-344. DOI: 10.14199/ppp-2013-093.

Thiem D., Szmidt-Jaworska A., Baum C., Muders K., Niedojadło K., Hrynkiewicz K. 2014. Interactive physiological response of potato (Solanum tuberosum L.) plants to fungal colonization and Potato virus Y (PVY) infection. Acta Mycologica 49 (2): 291-303. DOI: 10.5586/am.2014.015.

Wang B., Liu L., Gao Y., Chen J. 2009. Improved phytoremediation of oilseed rape (Brassica napus) by Trichoderma mutant constructed by restriction enzyme-mediated integration (REMI) in cadmium polluted soil. Chemosphere 74 (10): 1400-1403. DOI: 10.1016/j. chemosphere.2008.11.027. 